\title{
The Precambrian/Lower Cambrian pluton from Vila Nova (Central Portugal)
}

\author{
El plutón Precámbrico-Cámbrico Inferior de Vila Nova \\ (Centro de Portugal)
}

\begin{abstract}
A.I.M. Reis ${ }^{1}$, M.M.V.G. Silva ${ }^{1}$, I.M.H.R. Antunes ${ }^{2}$
ABSTRACT

The Vila Nova pluton is a small, Pre-Variscan granitic body that intruded rocks of the Central Iberian Zone near the contact with the Ossa Morena Zone and is affected by several shear zones and faults. Its contact metamorphic aureole is constituted by micaschist with porphyroblasts in the outer zone and hornfels in the inner zone. Small metasedimentar xenoliths are dispersed all over the body. The pluton has a great mineralogical heterogeneity with pronounced variations in muscovite/biotite and plagioclase/microcline contents and is classified as granite, granodiorite or tonalite. It is a leucogranite, highly peraluminous $(\mathrm{A} / \mathrm{CNK}=1.31-1.64)$, magnesian and calc-alkaline to alkaline-calcic. The variation diagrams show curvilinear trends with silica. $\mathrm{Eu} / \mathrm{Eu}^{*}=0.47-0.77$ and there is a slight enrichment in LREE relative to HREE. The normalized diagrams indicated dominantly crustal granite, related to subduction. $\mathrm{U}-\mathrm{Pb}$ isotopic data of zircon and monazite gives 540-542 Ma age.
\end{abstract}

Key words: granite, $\mathrm{U}-\mathrm{Pb}$ isotopic data, cadomian magmatism.

\section{RESUMEN}

El plutón de Vila Nova es un pequeño cuerpo granítico pre-varisco, que intruyó en las rocas de la Zona Centro lbérica, cerca del contacto con la Zona de Ossa Morena, siendo afectado por varias fallas y zonas de cizalla. Su aureola de metamorfismo de contacto consiste en esquistos con porfiroblastos y corneanas. Pequeños xenolitos metasedimentarios aparecen dispersos por todo el cuerpo granítico. Presenta una gran diversidad mineralógica, con amplias variaciones en las relaciones biotita/moscovita y microclina/plagioclasa, siendo clasificado como tonalita-granodiorita-granito. Se trata de un leucogranito fuertemente peralumínico $(\mathrm{A} / \mathrm{CNK}=1.31-1.64)$, magnesiano y calco-alcalino a alcalino-cálcico. Los diagramas muestran variaciones curvilíneas con la variación de sílice. Eu/Eu* $=0.47-0.77$ y hay un ligero enriquecimiento de LREE en relación con HREE. Los diagramas indican que la norma es un granito dominante de la corteza, relacionados con la subducción. Las relaciones isotópicas U-Pb en circón y monacita indican una edad de 540-542 Ma.

Palabras clave: granito, $\mathrm{U}-\mathrm{Pb}$ datos isotópicos, magmatismo cadomiano.

\section{Introduction}

One of the main purposes of modern petrology is the characterization of the process of renovation and accretion which control crustal evolution. Granitoids, well represented in orogenic domains, are the most important crust constituents and their origin is still an important objective in geochemistry investigations. Recent studies show that granitoids are important indicators of the mechanisms previously referred, due to their variable composition and geodynamic setting.

The age of granitoid rocks can be obtained by modern and highly accurate techniques and its

\footnotetext{
1 Earth Sciences Department, FCTUC. Geosciences Centre. Portugal. Email: anaimreis@ gmail.com, mmvsilva @ci.uc.pt

2 Polytechnic Institute of Castelo Branco. Geosciences Centre. Portugal. Email: imantunes@esa.ipcb.pt
} 


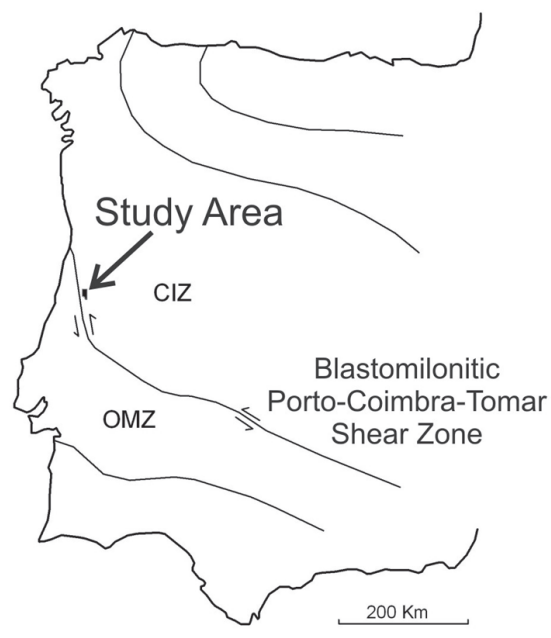

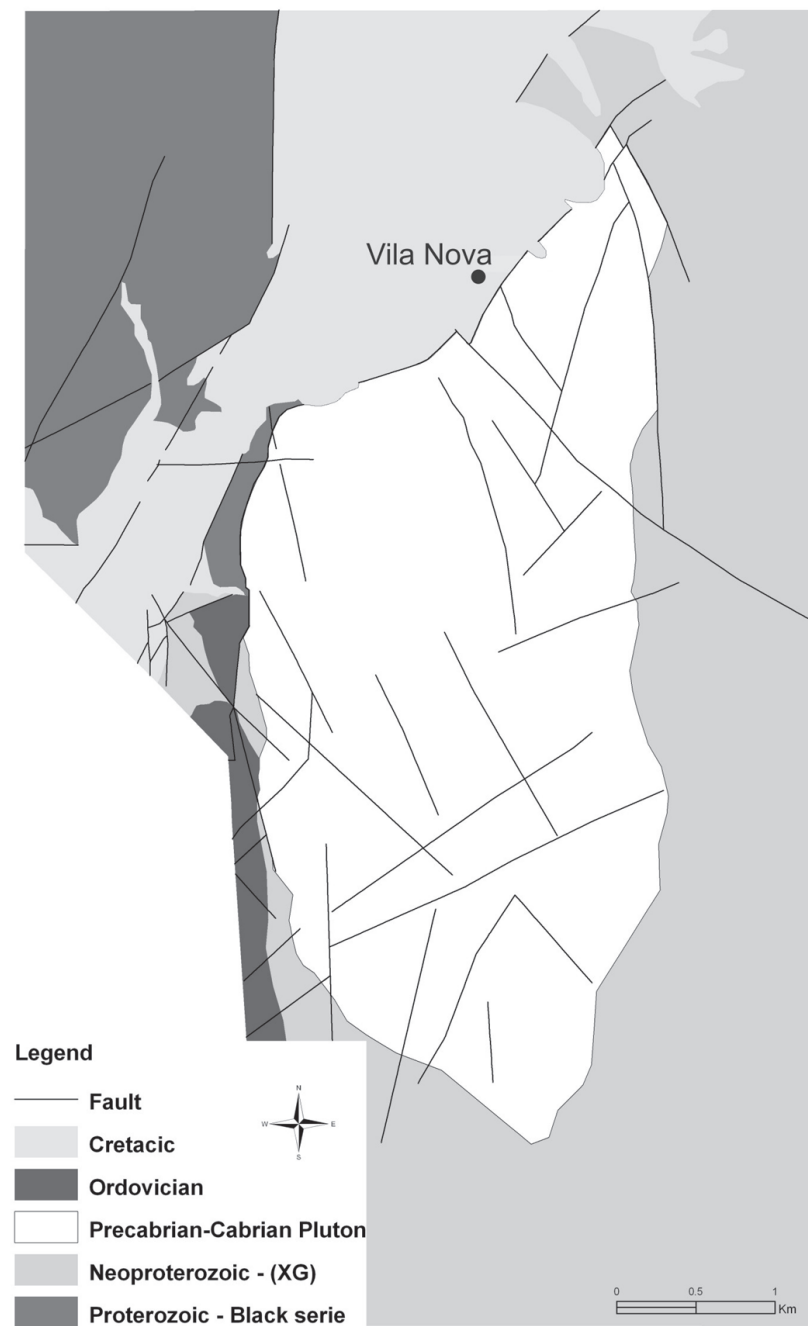

Fig. 1.-Location and geological scheme of the studied area (CIZ: Central Iberian Zone; OMZ: Ossa Morena Zone). determination allows the identification of important geologic episodes being a fundamental component in the study of the evolution of crustal orogenic processes (Carrigan et al., 2005).

In Portugal, close to the contact between the Central Iberian Zone (CIZ) and Ossa Morena Zone (OMZ), five small granitic plutons outcrop, including the Vila Nova pluton, which are intrusive in the Neoproterozoic/Cambrian Schist-Metagraywacke Complex metasediments. Several geochronological studies indicated an ante-Ordovician age for these plutons; e.g. a Rb-Sr whole rock age of $506 \pm 14 \mathrm{Ma}$ to the Coentral/Vila Nova granites (Abranches \& Canilho, 1981); a Rb-Sr whole rock age of $443 \pm 63$ Ma to the Coentral granite (Shepherd \& Oliveira, 1990); and $\mathrm{K}$-Ar biotite and muscovite ages for the Coentral granite (Gomes, 1990; Gomes et al., 1991), Pedrogão Grande and Figueiró dos Vinhos granites (Pereira, 1987; Pereira \& Macedo; 1983), indicating an age of 555-580 for muscovite and 524-570 for biotite.

This paper is focused on a mineralogical, geochemical and isotopic study (U-Pb), of the granitic pluton of Vila Nova, which intruded the fragility zone imposed by the Cadomian suture between the Central Iberian Zone and the Ossa Morena Zone of the Iberian Massif.

\section{Geological setting}

The pre-variscan Vila Nova granitic pluton, outcrops in the CIZ and intrudes the Neoproterozoic/ Cambrian Schist-Metagraywacke Complex, in Central Portugal. It has a slightly elliptical shape of approximately $15 \mathrm{~km}^{2}$, aligned in the N-S direction. To the West, the igneous body contacts with Proterozoic, Neoproterozoic and Ordovician rocks by a complex system of faults related to the Blastomilonitic Porto-Coimbra-Tomar shear zone (Fig 1).

To the East, the igneous body produced a metamorphic contact aureole with micaschist with porphyroblasts in the outer zone and hornfels in the inner zone. To the Northwest, the granitic rock contacts with sedimentary clastic rocks of Cretaceous age by a thrust (Fig. 1). The pluton is affected by several shear zones and faults, especially near the Blastomilonitic shear zone, and shows an intensive weathering, which results on strong and penetrative arenization.

Small metasedimentary xenoliths of centimetric dimensions are hosted by the granitic rock. They are surmicaceous and some have prismatic 
andalusite. Quartz ocellis (up to $10 \mathrm{~cm}$ long) occur dispersed all over the granite and small and thin (milimetric) quartz veins with chlorite are also found.

\section{Analytical methods}

Seven samples were collected for petrographic, geochemical and isotopic studies in the Vila Nova pluton. Sampling was conditioned by the limitations imposed by the alteration and outcrop scarcity of the area.

Samples were prepared in Earth Sciences Department, University of Coimbra (Portugal). Thin sections were made for modal analysis and petrographic studies. The samples were crushed in an agate mortar to $<75 \mu \mathrm{m}$. Major, trace and rare earth elements were determined by ICP-MS in Actlabs, Canada. $\mathrm{FeO}$ was determined by titration with potassium permanganate with a precision of $1 \%$, at the Earth Sciences Department, University of Coimbra.

The less altered granitic sample was chosen for $\mathrm{U}-\mathrm{Pb}$ ID-TIMS isotopic studies. It was grinded on a jaw crusher. The fraction inferior to $180 \mu \mathrm{m}$ was separated by heavy liquids and magnetic separation to obtain a concentrate of zircon and monazite.

A representative fraction of zircon was selected avoiding crystals with external disturbed domains, inclusions or zonation. After chemical treatment isotopic ratios were obtained by isotope dilution and thermal ionization mass spectrometry (IDTIMS), using a Finningan Mat 62 mass spectrometer at the Geosciences Department, University of Oslo (Norway), following Krogh (1982) methodology with the adaptations of Corfu (2004). The analysis accuracy and respective ages were obtained with $2 \alpha$ of significance degree. Results were plotted in Concordia diagrams (Krogh, 1982; Davidson \& Van Breemen, 1988).

\section{Mineralogy and geochemistry of granitoid rocks}

The Vila Nova granitic pluton contains quartz, perthitic microcline, albite-oligoclase, muscovite, biotite, apatite, zircon, monazite, rutile, pyrrhotite, magnetite, ilmenite, pyrite and tourmaline. The alteration minerals are muscovite and chlorite. The muscovite/biotite and plagioclase/K-feldspar ratios

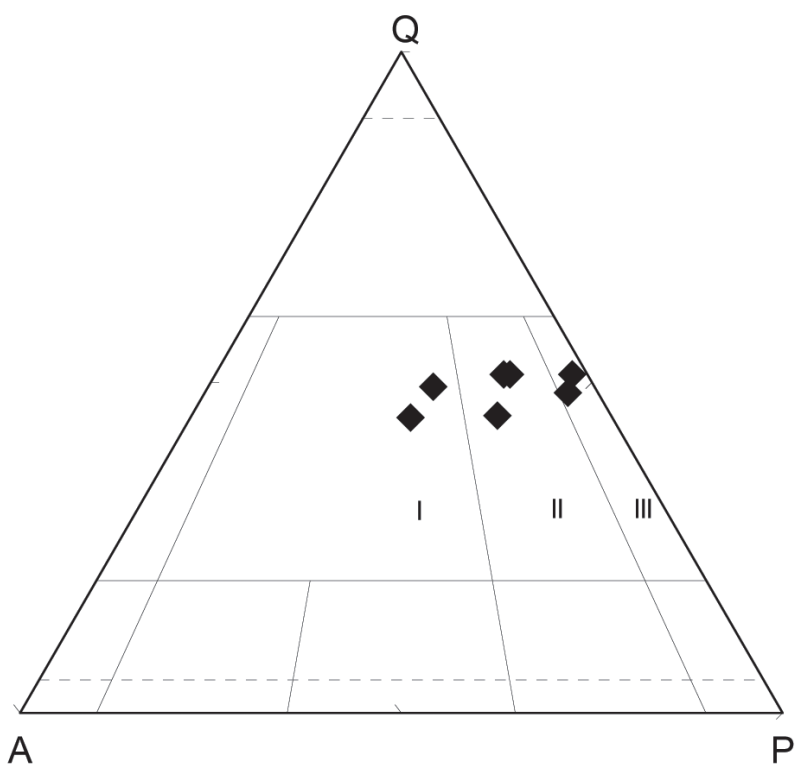

Fig. 2.-IUGS classification of granitic rocs after Le Maitre et al. (2005). Modal compositions are quartz (Q), plagioclase (P), alkaline feldspar (A). Areas are: granite (I), granodiorite (II) and tonalite (III).

are highly variable and the granitoid from Vila Nova is classified as tonalite-granodiorite-granite (Fig. 2), with different quantities of muscovite and biotite.

The granitoid rock is a leucogranite, peraluminous, with $\mathrm{A} / \mathrm{CNK}$ ranging from 1.31 to 1.69 and can be classified as a S-type granite. It is also classified as a magnesian, calc-alkaline to alkaline-calcic granite (Frost et al., 2001) or as a volcanic arc granite (Fig. 3a, b, c) (Pearce et al., 1984). The Ocean Ridge Granite (ORG) and the Primordial Mantle normalized patterns indicates that is a crustal granite (Fig. 3d), related to subduction (Fig. 3e), with positive anomalies for $\mathrm{Rb}, \mathrm{Th}, \mathrm{Ce}$ and $\mathrm{Sm}$ and negative anomalies for $\mathrm{Ba}, \mathrm{Ta}, \mathrm{Nb}, \mathrm{Sr}$ and Ti (Fig. 3d, e).

Variation diagrams (not presented here) show regular curvilinear trends with decrease in $\mathrm{TiO}_{2}$, $\mathrm{Al}_{2} \mathrm{O}_{3}, \mathrm{FeO}, \mathrm{MgO}, \mathrm{Ba}, \mathrm{Sc}, \mathrm{V}, \mathrm{Cr}, \mathrm{Ni}, \mathrm{Nb}, \mathrm{Zr}, \mathrm{Hf}$ and $\sum \mathrm{REE}$ with $\mathrm{SiO}_{2}$ increase, $\mathrm{K}_{2} \mathrm{O}$ and $\mathrm{Rb}$ show segmented trends, while $\mathrm{CaO}, \mathrm{Sr}$ and $\mathrm{Cs}$ don't show any trend, which can be due to the hydrothermal alteration (Reis, 2009).

The REE patterns, normalized to chondrite, show a moderate negative Eu anomaly (0.47-0.77) and a moderate fractionation for REE $\left(\mathrm{La}_{\mathrm{N}} / \mathrm{Lu}_{\mathrm{N}}=7.04\right.$ to 9.65) (Fig. 4). The $\sum$ REE varies from 126.84 to $179.61 \mathrm{ppm}$. 

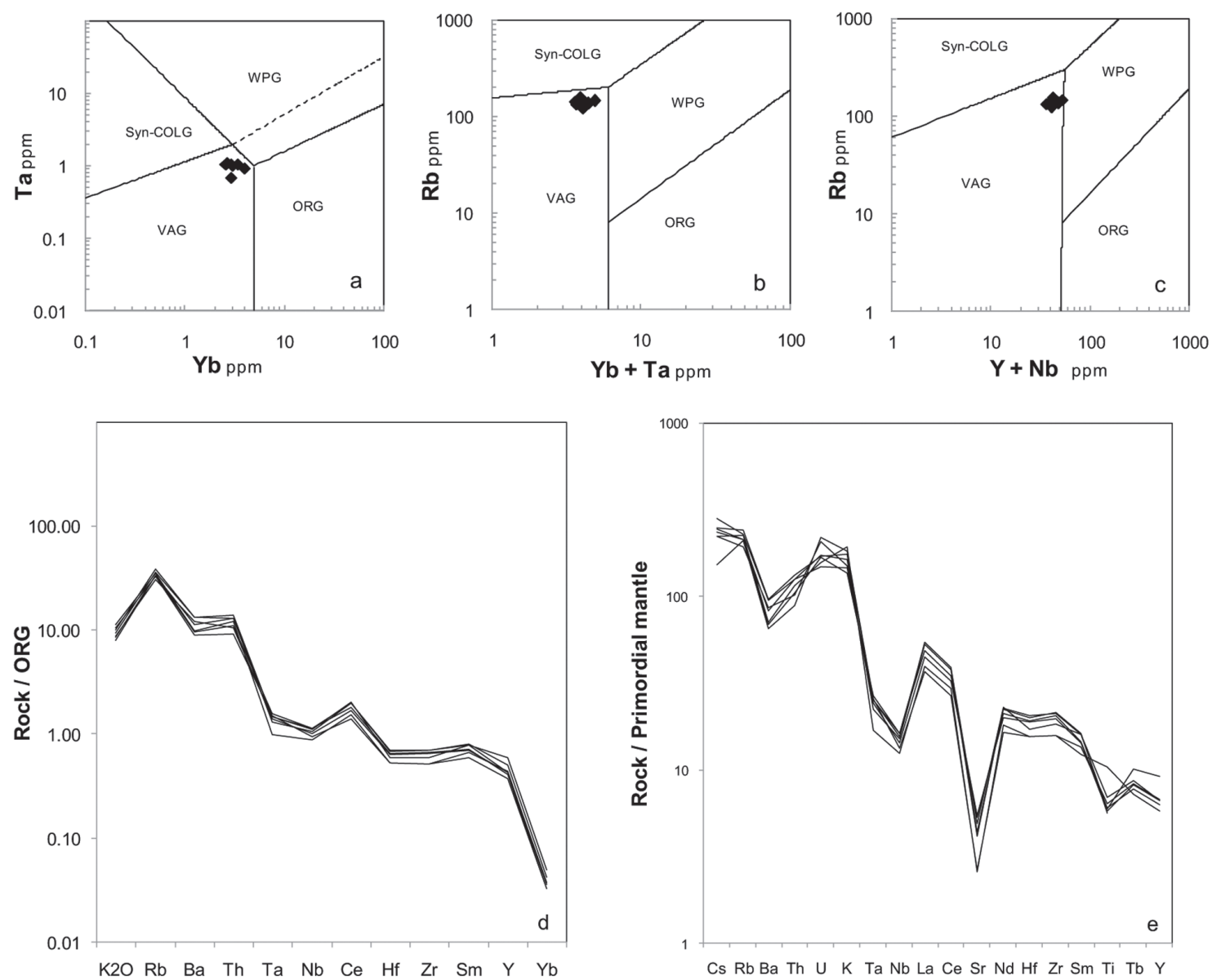

Fig. 3.-Tectonic environment diagrams: $\mathrm{Yb}-\mathrm{Ta}(\mathrm{a})$; $\mathrm{Rb}-(\mathrm{Y}+\mathrm{Ta})$, (b); Rb-(Yb+Nb), (c). Syn-collisional granites (Syn-COLG), intra-plate granites (WPG), oceanic rift granites (ORG) and volcanic arc granite (VAG) (Pearce et al., 1984). Geochemical normalized pattern to ORG (Ocean Ridge Granite; Pearce et al., 1984) (d). Geochemical normalized pattern to primordial mantle (McDonough et al. 1992) (e).

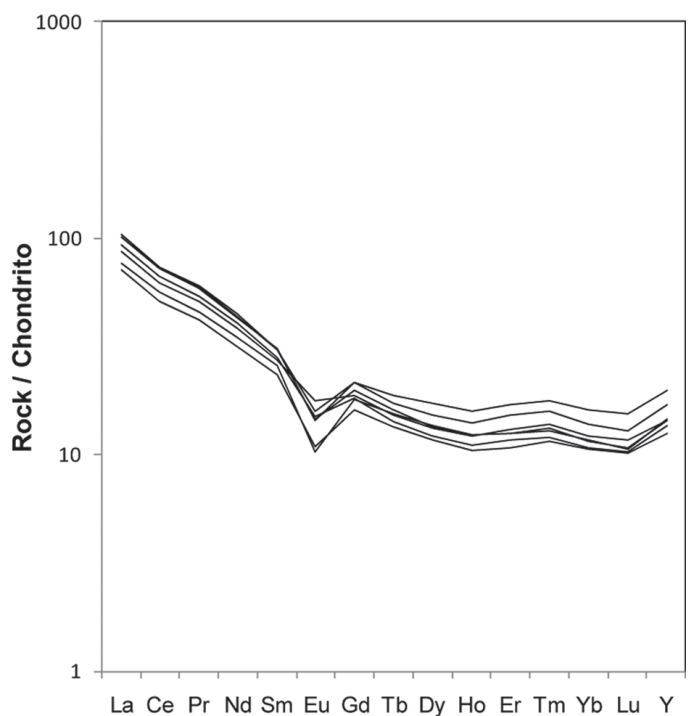

Fig. 4.-REE diagram normalized to chondrite (Taylor \& McLennan, 1985).

\section{Isotope geochemistry}

The least altered sample from Vila Nova pluton was selected for $\mathrm{U}-\mathrm{Pb}$ isotopic data determination. In this sample five fractions of zircon and two fractions of monazite were analysed. The selected crystals have prismatic habit and are colourless. They do not present inclusions, fractures or disturbed domains.

On the concordia diagram, ${ }^{206} \mathrm{~Pb} /{ }^{238} \mathrm{U}$ versus ${ }^{207} \mathrm{~Pb} /{ }^{235} \mathrm{U}$, three zircon fractions are plotted on the Concordia, while two zircon fractions are discordant and define an inverse discordia curve (Fig. 5). The age defined by the three concordant zircon fractions is $541.2 \pm 0.8 \mathrm{Ma}(\mathrm{MSWD}=1.3)$. The inverse discordia curve intercepts the concordia curve in the lower part, with a minimum emplacement age of $540.4 \pm 0.8 \mathrm{Ma}$ and an upper interception age of $1887 \pm 17 \mathrm{Ma}$ and a MSWD of 0.65 . 

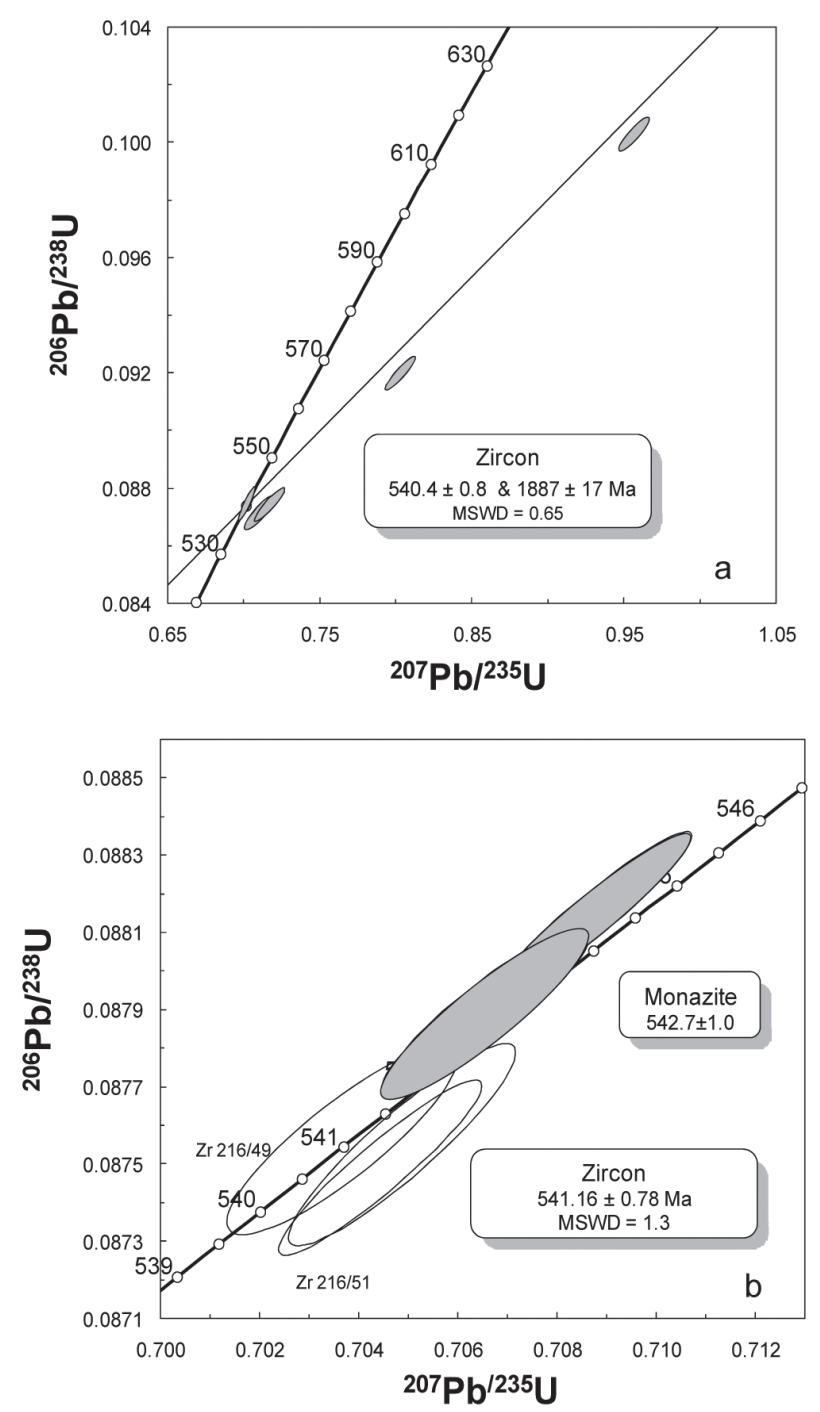

Fig. 5.-Concordia diagrams to zircon (a) and zircon and monazite (b) from selected sample of Vila Nova pluton. zr: zircon, $\mathrm{mz}$ : monazite.

The reversely discordance of zircon could suggest a $\mathrm{Pb}$ inheritance associated with an initial ${ }^{230} \mathrm{Th}$ disequilibrium (Shrärer, 1984; Kalt \& Corfu, 2000), a probable small zircon inheritance or an isotopic disturbance (Corfu, 2004).

The more concordant zircon indicates a ${ }^{207} \mathrm{~Pb} /{ }^{206} \mathrm{~Pb}$ age of $540.5 \pm 0 \mathrm{Ma}$, with a discordance of $0.1 \%$, identical to the other zircon fraction ages obtained.

The monazite fractions are concordant, although they tend to plot far from zircon, because they are easily affected by disturbances associated to the geologic episodes (Kalt \& Corfu, 2000), showing a ${ }^{206} \mathrm{~Pb}$ excess due to the ${ }^{230} \mathrm{Th}$ incorporated during monazite crystallization (Schärer, 1984). The mon- azite crystal that plots close to the zircon has a ${ }^{207} \mathrm{~Pb} /{ }^{235} \mathrm{U}$ age of $542.7 \pm 1.0 \mathrm{Ma}$.

The magmatic emplacement age is of $541.2 \pm 0.8$, according to the three concordant zircon fractions. The range 540-542 Ma is the possible period of installation to the Vila Nova Pluton, with an Precambrian-Cambrian age.

\section{Conclusions}

The Vila Nova Pluton is a heterogeneous peraluminous granitic rock. This pluton has a crustal origin, subduction related, that intruded near the suture between the CIZ and the OMZ in the Precambrian-Cambrian transition. The $\mathrm{U}-\mathrm{Pb}$ age, obtained with concordant zircon and monazite age is $541.2 \pm 0.8 \mathrm{Ma}$. This result defines a range of 540-542 Ma for the pluton emplacement.

The Vila Nova Pluton and probably the other plutons of the area are indicative of an igneous activity in the CIZ, related to Cadomian Orogeny and strongly affected by the Variscan orogeny. The Vila Nova pluton is an evidence of a crustal renewal episode during the Precambrian-Cambrian transition in the CIZ, also suggested by Neves et al. (2001) for other granitc plutons in the same geotectonic setting.

\section{References}

Abranches, M.C.B. \& Canilho, M.H. (1981). Determinação da idade pelo método do $\mathrm{Rb}$-Sr de granitos antigos portugueses. Memórias da Academia das Ciências de Lisboa, 24: 17-31.

Carrigan, C.W.; Mukasa, S.B.; Haydoutov, I. \& Kolcheva, K. (2005). Age of Variscan magmatism from the Bakan sector of the orogen central Bulgária. Lithos, 82: 125-147. doi:10.1016/j.lithos.2004.12.010

Corfu, F. (2004). U-Pb geochronology of the Lekres group: an exotic Early Caledonian metassedimentary assemblage stranded on Lofoten basement, northern Norway. Journal of the Geological Society of London,161: 19-627. doi:10.1144/0016764903-066

Davidson, A. \& Van Breemen, O. (1988). Baddeleyite-zircon relationships in coronitic metagrabo, Grenville Province, Ontario: Implications for geochronology. Contributions to Mineralogy and Petrology, 100: 91-299. doi:10.1007/BF00379740

Frost, B.R.; Barnes, C.G.; Collins, W.J.; Arculus, R.J.; Ellis, D.J. \& Frost, C.D. (2001). A geochemical classification for granitic rocks. Journal of Petrology, 42: 2033-2048. doi:10.1093/petrology/42.11.2033

Gomes, E.M.C. (1990). O Plutonito do Coentral - Considerações sobre a petrografia, geoquímica, idade 
deformação e metamorfismo. Tema de dissertação apresentado no âmbito das Provas de Aptidão Pedagógica e Capacidade Científica, Univ. Coimbra, 148 pp.

Gomes, E.M.C.; Pereira, L.C.G. \& Macedo, C.A.R (1991). O Plutonito do Coentral: idade K-Ar e consequências geotectónicas. Memórias e Notícias, Publicações do Museu e Laboratório Mineralógico e Geológico da Universidade de Coimbra, 112: 171-183.

Kalt, A. \& Corfu, F. (2000). Time calibration of a P-T path from a Variscan high temperature low-pressure metamorphic complex (Bayerische Wald, Germany) and the detection of inherited monazite. Contributions to Mineralogy and Petrology, 138: 143-163. doi: $10.1007 / \mathrm{s} 004100050014$

Krogh, T.E. (1982). Improved accuracy of U-Pb zircon ages by creation of more concordant systems using an air abrasion technique. Geochimica et Cosmochimica Acta, 46: 637-649. doi:10.1016/0016-7037(82)90165-X

Le Maitre, R.W.; Streckeisen, A.; Zanettin, B.; Le Bas, M.J.; Bonin, B. \& Bateman, P. (2005). Igneous Rocks. A classification and glossary of terms. $2{ }^{\text {nd }}$ Edition, Cambridge University Press, 256 pp. doi: $10.2277 / 0521619483$

McDonough, W.F.; Sun, S.; Ringwood, A.E.; Jagoutz, E. \& Hofmann, A.W. (1992). Potassium, rubidium, and cesium in the Earth and Moon and the evolution of the mantle of the Earth. Geochimica et Cosmochimica Acta, 56: 1001-1012. doi:10.1016/0016-7037(92)90043-I

Neves, L.J.P.F.; Pereira, A.J.S.C.; Stephens, W.E.; Godinho, M.M. \& Pereira, L.C.G. (2001). Geoquímica dos plutonitos graníticos ante-hercínicos de Figueiró dos Vinhos e Bouçã (Portugal Central). Actas do VI Congresso de Geoquímica dos Países de Língua Portuguesa, 223-227.
Pereira, L.C.G. (1987). Tipologia e evolução da sutura entre a $Z C I$ e a $Z O M$ no sector entre Alvaiázere e Figueiró dos Vinhos (Potugal Central). Tese de doutoramento, Univ. Coimbra, $331 \mathrm{pp}$.

Pereira, L.C.G. \& Macedo, C.A.R. (1983). Sobre a idade do granito de Figueiró dos Vinhos, Pedrogão Grande e de um pegmatito do Casal do Zote (Dornes) no sector da sutura da Zona de Ossa Morena-Zona Centro Ibérica, a norte de Tomar (Portugal Central): algumas implicações geotectónicas. Comuniações dos Serviços Geológicos de Portugal, 69: 256-266.

Pearce, J.; Harris, N.B.W. \& Tindle, A.G. (1984). Trace element discrimination diagrams for the tectonic interpretation of granitic rocks. Journal of Petrology, 25: 956-983.

Reis, A.I.M. (2009). O plutonito de Vila Nova - Caracterização Geológica, mineralogia, geoquímica e contributo para o ordenamento. Tese de Mestrado em Geociências, Universidade de Coimbra, 89 pp.

Schärer, U. (1984). The effect of initial ${ }^{230}$ Th disequilibrium on young U-Pb ages: the Makalu case, Himalaya. Earth and Planetary Science Letters, 67: 191-204. doi:10.1016/0012-821X(84)90114-6

Sherpherd, T.J. \& Oliveira, J.M.S. (1990). Hydrothermal fluid anomalies: A new strategy for exploration in Portugal. Joint Project between British Geological Survey (UK) and Direcção Geral de Geologia e Minas (Portugal). Final Report. XX pp.

Taylor, S.R. \& Mclennan, S.M. (1985). The continental crust: its composition and evolution. Blackwell Scientific Publ., Oxford. 311 pp.

Recibido el 25 de noviembre de 2009 Aceptado el 2 de febrero de 2010 Publicado online el 11 de mayo de 2010 